\title{
A BIRD'S-EYE VIEW OF THE LOAN SHARK PROBLEM FROM THE OFFICES OF THE LEGAL AID SOCIETY IN ATLANTA, GEORGIA
}

\author{
Carolyn M. Pennisi*
}

\section{Founding of the Atlanta Legal Aid Society}

In I924, a group of public-spirited Atlanta lawyers, interested in setting up an agency to furnish to the poor needed legal service, organized and incorporated the Atlanta Legal Aid Society. An attorney was engaged and an office opened. The following year financing was taken over by the Community Chest. The work has continued and grown since that time, enabling thousands unable to pay for legal service in the area to have counsel, of which they otherwise would be deprived.

During the early years of its operation, the Society, together with the Atlanta Bar Association and other civic groups, carried on a drive against usurious money lenders, who were thriving at that time and causing much misery. These efforts greatly improved the position of the poor borrowers, by obtaining relief for them in court and by bringing about stronger laws on money lending and a decrease in illegal operations of loan companies.

\section{Laws in Effect on Money Lending in 1924}

When the Society commenced its activities there were a number of laws in effect in Georgia on money lending. Several old laws regulating interest and usury were in existence, which provided a maximum rate of interest of 8 per cent per annum, ${ }^{1}$ and that a charge of more than 8 per cent would cause forfeiture of the entire interest. ${ }^{2}$ These provisions remain today.

A Ig04 law required licensing and other regulation of the business (I) of making loans on the security of household or kitchen furniture, household goods, wearing apparel, sewing machines, musical instruments, wages, or salaries, and (2) of buying wages or salaries. ${ }^{3}$ It provided for fees for investigating security, ${ }^{4}$ but provided also that any interest charged in excess of the legal rate, or any fees above those specified in the law, and any charge of more than 6 per cent of the amount of any loan of more than $\$ 60$, would be considered as payment on principal. ${ }^{5}$ It further

- Attorney, Legal Aid Society, Atlanta, Georgia, since 1944. Graduated from University of Georgia in 1939 and the Atlanta Law School in 1944. Member of the Georgia bar. Past president of the Georgia Association of Women Lawyers; and member of Phi Kappa Phi and Beta Gamma Sigma honorary fraternities.

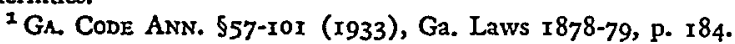

2 GA. COde ANN. \$57-112 (1933), Ga. Laws 19i6, p. 48.

Ga. Code Ann. \$25-201 (1933), Ga. Laws r904, p. 79.

- Ga. Code Ann. \$25-213 (1933), Ga. Laws 1904, pp. 79, 82.

${ }^{-}$Ga. Code ANN. \$25-215 (1933), Ga. Laws 1904, pp. 79, 83. 
provided that any contract for the assignment of unearned wages for the purpose of securing a loan of money was void. ${ }^{6}$ This law has not been specifically repealed.

A I908 law was in effect providing that no one should charge more than 5 per cent a month on a loan, ${ }^{7}$ and that violation of this prohibition would be a misdemeanor. ${ }^{8}$ A I9I2 law allowed a rate of 6 per cent a year for monthly installment loans, aggregating the principal and interest for the entire period of the loan, and dividing into installments, ${ }^{9}$ which in effect allowed almost 12 per cent a year on the average balance. These laws are still in effect.

A I9I3 law provided for loans by Building and Loan Associations and "Other Like Associations," at 8 per cent per annum, and allowed the principal and interest to be aggregated for the entire period of the loan, and divided into monthly or other installments. It provided that the loan could be secured by certificates of indebtedness, payable on the installment plan, bearing additional interest. ${ }^{10}$ In effect, interest under this law could be almost as much as 32 per cent per annum on the average balance, and other charges were also permissible. This law is still in operation.

A I920 law was in effect, regulating the "Small Loan Business." This required licensing by the State Superintendent of Banks of businesses making loans of $\$ 300$ or less, charging more than 8 per cent per annum, ${ }^{11}$ and permitted licensees to charge $3^{1 / 2}$ per cent a month interest, with no additional charges allowed, and provided that if a licensee charged more it would forfeit principal and interest. ${ }^{12}$ Violators of these provisions could be found guilty of a misdemeanor. ${ }^{13}$ This law was later changed to decrease the rate allowed to $I \frac{1}{2}$ per cent a month.

A I925 law provided that credit unions could charge members I per cent a month, plus other fees prescribed in the by-laws. ${ }^{14}$ This is now in effect.

\section{Subsequent Improvements in Money Lending Laws}

Due to a large extent to the efforts of the Legal Aid Society, the Atlanta Bar Association, and other interested civic groups, the Georgia laws on money lending were clarified and strengthened after I924.

In I93 the Georgia Supreme Court held that a consent judgment signed by a borrower before suit was filed was void. ${ }^{15}$ This decision helped eliminate much grief to borrowers, for the lenders previously had been getting borrowers to sign papers consenting to judgment without notice, and when the borrowers failed to

${ }^{\circ}$ Ga. Code Ann. $\$ 25-220$ (1933), Ga. Laws I904, pp. 79, 84 .

7 Ga. Code Ann. \$57-II7 (1933), Ga. Laws 1908, p. 83 .

${ }^{8}$ Ga. Code AnN. \$57-9901 (1933), Ga. Laws 1908, p. 83.

${ }^{\circ}$ Ga. Code AnN. \$57-116 (1933), Ga. Laws 1912, p. I44.

${ }^{10} \mathrm{GA}$. Code ANN. \$16-1or (1933), Ga. Laws 1913, p. 54 .

${ }^{11}$ GA. Code ANn. $\$ 25-301$ (I933), Ga. Laws I920, p. 215.

${ }^{12}$ Ga. Code AnN. \$25-313 (1933), Ga. Laws 1920, p. 219.

${ }^{13}$ GA. Code ANN. \$25-9902 (1933), Ga. Laws 1920, pp. 215, 221.

${ }^{14}$ Gs. Cone AnN. \$25-116 (1933), Ga. Laws 1925, p. 175.

${ }^{15}$ Information Buying Co. v. Miller, 173 Ga. 786, I6I S. E. 617 (I93I). 
pay, they. had the judgment signed by the court, and then began garnishment proceedings.

In 1933 the garnishment law was changed, to provide that no garnishment should issue against the daily, weekly or monthly wages of any person residing in Georgia, until after a final judgment had been rendered against him. ${ }^{16}$ Prior to this law, lenders had a great advantage over their borrowers because they could run a garnishment and endanger the borrower's job, before the borrower had a chance to contest the debt.

In 1934 the Georgia Supreme Court in Parsons v. Fox held that the particular "salary buying" transactions in this case were not bona fide assignments of wages, but were loans, and were subject to civil and criminal usury laws. ${ }^{17}$ The facts in this case were that the lender paid the borrower a sum of money upon the execution by the borrower of what purported to be an assignment of a larger sum due the borrower from his employer; the paper gave the lender the right to collect the money, but he made no attempt to do so and served no notice on the employer. The borrower collected his wages, and then had another transaction under which the first paper was canceled and a new one signed, differing from the first only as to dates. There was then an exchange of funds under which the lender received a net amount of $\$ 2.25$. This procedure was repeated on subsequent paydays, and the borrower never received any sum in addition to the amount originally received.

Parsons $v$. Fox opened the way to many subsequent decisions by the court that so-called salary assignments were in fact usurious loans, and the borrowers thus were relieved.

In 1935 the "Small Loan Rate" was reduced to $\mathrm{I}^{1 / 2}$ per cent a month, ${ }^{18}$ and in I945 the rate of pawnbrokers was clarified and fixed at 2 per cent a month. ${ }^{10}$ In I953 the Georgia Court of Appeals held that where the cost of insurance charged by a lender actually represented a device for the reservation of interest, then the amount of such charge would be considered in determining whether the lender had violated the usury laws. The conviction of the lender in this case of charging more than 5 per cent a month interest was upheld. ${ }^{20}$

\section{Present-Day Regulations}

Under the present laws in Georgia the following interest rates are allowed. The regular maximum rate of interest is 8 per cent per annum; ${ }^{21}$ the monthly installment rate is 6 per cent on the original amount for the entire period of the loan, or almost I2 per cent on the average balance; ${ }^{22}$ the Building and Loan and "Other Like Association" rate is 8 per cent on the original amount for the period of the loan, or almost

${ }^{10} \mathrm{GA}$. CODE ANn. $\$ 46$-Ior (1933), Ga. Laws 1933, p. 35 .

${ }^{17}$ Parsons v. Fox, 179 Ga. 605, I76 S. E. 642 (1934).

${ }^{28} \mathrm{GA}$. CODE ANN. I933, \$25-313 (1933), Ga. Laws 1935, p. 394.

${ }^{20}$ Ga. Code ANn. \$12-612 (1933), Ga. Laws 1945, p. I89.

${ }^{20}$ Peebles v. State, 87 Ga. App. 649, 75 S. E. $2 d$ 35 (1953).

${ }^{21} \mathrm{G}$. CODE ANN. $\$ 57-101$ (1933), Ga. Laws $1878-89$, p. I84.

${ }^{22}$ GA. CODE ANN. \$57-I 6 (1933), Ga. Laws I9I2, p. I44. 
$3^{2}$ per cent on the average balance, taking into consideration the certificates of indebtedness that are issued by the company and used as security, being purchased on the installment plan at interest; ${ }^{23}$ the special "Small Loan Rate" is $I \frac{1}{2}$ per cent a month, or 18 per cent per annum on the unpaid balance ${ }^{24}$ (there are only two companies licensed at present in the state under this law); the credit union rate is $x$ per cent a month, plus other fees; ${ }^{25}$ and the pawnbroker rate is 2 per cent a month, with a minimum of $5^{\circ}$ cents a month. ${ }^{28}$

Although the laws have been improved in favor of borrowers, still there remain many disadvantages for them. There is a great disadvantage in the rates allowed to Building and Loan and "Other Like Associations," which can run to almost $3^{2}$ per cent a year plus other charges. Also disadvantageous is the "time price" law used in automobile financing. The court has held that where such a price is agreed upon, no question of usury is involved. ${ }^{27}$ Thus the charges for financing on the time price arrangement are unlimited.

Even those loan companies that operate illegally are sometimes hard to combat because they furnish their customers few evidences of the debt and payments, their customers do not understand what happened and have poor memories, and the companies may conveniently lose their records when. prosecuted.

\section{Many Cases Involving Loan Companies Handled by the Society}

The Society, since its founding in I924, has been appealed to for help by thousands of the poorer residents of the area. Large numbers of these people have been borrowers, and many, victims of loan sharks. Most of the clients are ignorant and many are under great emotional stress. Some have been in terrible distress because of garnishment, or eviction, or death of the family provider. Some have been so confused that they could not even give their correct names.

Typical of the clients, however, is the negro man with a large family to support on $\$ 35$ a week, who tells the attorney that he has already had a summons of garnishment served on his employer by the XYZ Loan Company, although he has paid his loan off. (He did not understand when he was sued and let the case go in default.) $\mathrm{He}$ is going to lose his job unless helped. He is found to be fortunate in one respect; he does have receipts to show the money he has paid the finance company. His receipts total $\$ 102.88$. He has no other papers, and his recollection is that he borrowed a total of $\$ 65$ over a period of three months. He does not know how much he was supposed to have paid as interest. He remembers that he borrowed $\$ 15$ on July 15 , and agreed to pay back $\$ 18$ in two weeks; he borrowed $\$ 15$ on August $\mathrm{I}$, and agreed to pay back $\$ 18$ in two weeks; he borrowed \$ro on September $\mathrm{I}$, and agreed to pay back \$12 in two weeks; he borrowed $\$ 25$ on October $\mathrm{r}$, and agreed to pay back $\$ 30$ in two weeks. This totaled $\$ 65$ received. On October 15, the loan

${ }^{23}$ GA. Code ANN. §I6-roI (1933), Ga. Laws 19r3, p. 54.

26 GA. CODE ANN. \$25-313 (1933), Ga. Laws 1935, p. 394 .

${ }^{25}$ GA. CODE ANN. \$25-116 (1933), Ga. Laws 1925, p. 175.

${ }^{20} \mathrm{GA}$. Code ANN. \$12-612 (I933), Ga. Laws 1945, p. 189.

${ }^{27}$ Richardson v. C. I. T. Corp., 60 Ga. App. 780, 5 S. E. $2 d 250$ (1939). 
company generously proposed, he recalled, a new plan of payment for the balance still due on the last loan. They allowed him to bring in a payment on the last loan twice a month. Each time he made his semi-monthly payment he obtained a receipt and was told what to bring the next time, and each time he paid he was persuaded to sign another piece of paper. He never knew what writing these pieces of paper contained, as he did not read well, and he was not given anything in writing to show to someone who could read for him.

Although he brings his receipts for payments of \$102.88 to the Society office, on loans totalling $\$ 6_{5}$, there has already been issued against him a judgment for an additional $\$ 37.99$, and his wages have been subjected to garnishment. The Society attorney in this case was able to have the default judgment set aside, and filed a defense of usury. At this point the company gave up and released the garnishment, pursuing the matter no further. The money paid into court on the garnishment was turned over to the happy client.

Also typical, and duplicated by many more like it, is the case of the negro maid, who, over a period of several years, got herself into debt with more than a dozen different loan companies. In order to try to keep up with which companies she owed and when the payments were due she carried around in her worn pocketbook a large bundle of receipts and collection notices. Naturally by the time she reached the Legal Aid office many of the receipts had been lost. In order to stop the clamoring of these various companies for their payments, she had obtained a loan of several hundred dollars with another company, and with this paid off the first ones. She gave as security her furniture, which she had acquired after years of work. No sooner had she stopped the duns of the first companies, than she needed more money to pay the large loan and her living expenses, and she was obliged to return to the first companies and ask for more loans. It is amazing that credit was again given her and new loans made by the original companies.

When she reached the Society office her indebtedness had reached considerably over \$rooo and she had no way to pay it. Although certain of the loans could be attacked on the ground of usury, there were still too many unassailable ones for her ever to get out of debt, and she had to resort to bankruptcy, and give up her furniture.

Many unfortunate borrowers have come to the office with only a few smudged receipts for part of the money paid, or none at all, and with nothing in writing concerning the transactions with the loan companies. This lack of written memoranda, coupled with foggy recollections of the transactions by the clients, necessitates perseverance on the part of the attorneys to accomplish anything. These cases, however, never fail to arouse the deepest interest and sympathy, because the borrowers are so easily taken advantage of. There are some I75 lending agencies in Atlanta and its environs, and an estimated population of 725,000 souls in the area. Many of the poorer citizens will become involved with one or more of these loan companies, and will need help.

The society has since its establishment handled over $76,6 \mathrm{ro}$ cases. The following 
table shows the number of cases handled from the year 1928 through the first seven months of 1953 .

TABLE A

\begin{tabular}{|c|c|c|c|}
\hline Year & Number of Cases & Year & Number of Cases \\
\hline \multirow[t]{2}{*}{ 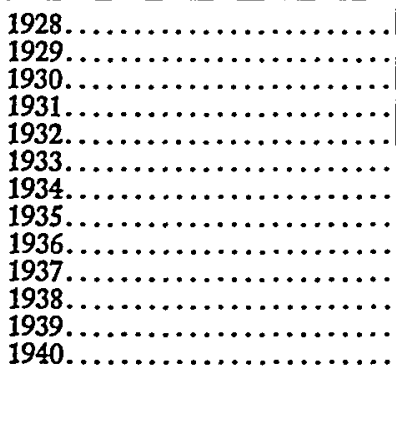 } & \multirow[t]{2}{*}{$\begin{array}{l}1054 \\
1236 \\
1758 \\
2784 \\
3049 \\
3089 \\
2670 \\
2772 \\
3822 \\
2791 \\
2816 \\
3056 \\
3087\end{array}$} & \multirow[t]{2}{*}{ 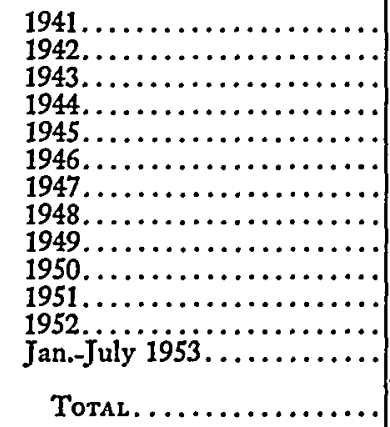 } & $\begin{array}{l}3044 \\
2809 \\
2805 \\
2866 \\
2699 \\
2461 \\
3024 \\
2986 \\
3436 \\
3824 \\
4588 \\
5156 \\
2928\end{array}$ \\
\hline & & & 76,610 \\
\hline
\end{tabular}

About half the cases concerned domestic relations matters, and the others involved a variety of matters, from loan shark problems to the question of how to open a grave. The following table gives a comparison of the cases handled from 1945 through x952, showing those involving domestic relations and those concerning indebtedness to loan companies. Domestic cases have comprised almost one-half the cases, but those where borrowers complained about loan companies were only a small portion of the cases, though they did rise from .6 per cent in 1945 to 2.9 per cent in 1952. The 508 cases on loans involved 568 different transactions.

Table B

\begin{tabular}{|c|c|c|c|c|c|c|}
\hline Year & $\begin{array}{l}\text { Number } \\
\text { of Cases } \\
\text { Handled }\end{array}$ & $\begin{array}{l}\text { Number } \\
\text { Concerning } \\
\text { Domestic } \\
\text { Relations }\end{array}$ & $\begin{array}{l}\text { Per Cent of } \\
\text { Domestic } \\
\text { Cases to } \\
\text { Total }\end{array}$ & $\begin{array}{l}\text { Number } \\
\text { Re Debts } \\
\text { to Loan } \\
\text { Companies }\end{array}$ & $\begin{array}{l}\text { Per Cent } \\
\text { of Debt } \\
\text { Cases to } \\
\text { Total }\end{array}$ & $\begin{array}{l}\text { Number } \\
\text { of Loan } \\
\text { Transactions } \\
\text { Involved }\end{array}$ \\
\hline 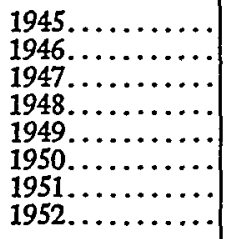 & $\begin{array}{l}2699 \\
2461 \\
3024 \\
2986 \\
3436 \\
3824 \\
4588 \\
5156\end{array}$ & $\begin{array}{l}1389 \\
1130 \\
1299 \\
1350 \\
1616 \\
1733 \\
2051 \\
2678\end{array}$ & $\begin{array}{l}50.4 \\
45.9 \\
43.0 \\
45.2 \\
47.0 \\
45.3 \\
44.7 \\
51.9\end{array}$ & $\begin{array}{r}15 \\
22 \\
47 \\
47 \\
65 \\
62 \\
99 \\
151\end{array}$ & $\begin{array}{l}0.6 \\
0.9 \\
1.6 \\
1.6 \\
1.9 \\
1.6 \\
2.2 \\
2.9\end{array}$ & $\begin{array}{r}15 \\
25 \\
52 \\
49 \\
76 \\
73 \\
104 \\
174\end{array}$ \\
\hline Totals... & 28,174 & 13,246 & & 508 & & 568 \\
\hline
\end{tabular}

An analysis of the $x 5^{\mathrm{I}}$ loan cases handled in $x 952$ reveals that 44.4 per cent of the debts were for the purpose of buying cars, and 15.8 per cent were for the purpose of buying or improving real estate, as is shown in the following table. A large number of clients came to the Society office after their cases were already lost, 
which emphasizes the need for more education of the public on the need for early legal advice.

Table C-Analysis of I5I Debt Cases in I952

\begin{tabular}{|c|c|c|}
\hline 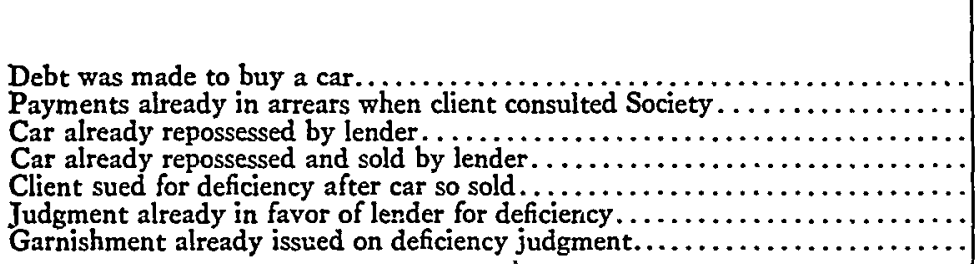 & $\begin{array}{l}\text { Number } \\
67 \\
65 \\
46 \\
39 \\
27 \\
8 \\
7\end{array}$ & $\begin{array}{c}\text { Per Cent } \\
\text { of } 151 \\
44.4 \\
43.0 \\
30.5 \\
25.8 \\
17.9 \\
5.3 \\
4.6\end{array}$ \\
\hline 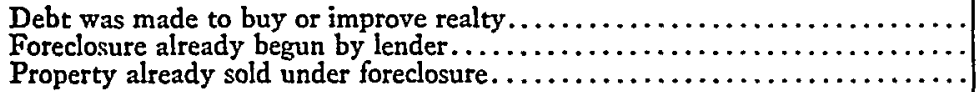 & $\begin{array}{r}24 \\
5 \\
3\end{array}$ & $\begin{array}{r}15.8 \\
3.3 \\
1.9\end{array}$ \\
\hline
\end{tabular}

\section{Study of Court Cases in i953 to See How Many Were Brought by Loan Companies}

In an effort to find out something about the litigation between loan companies and their borrowers at the present, the records of the Civil Court of Fulton County in Atlanta, Georgia, were checked for the months of January and February, 1953. In this court most of the suits against small borrowers in Atlanta are filed. It was found that out of a total of 7,186 civil actions filed, 54 per cent were brought by lending agencies, but only a pitifully small number were contested by the borrowers ( 0.4 per cent) and some of them had already lost their cases when the records were checked. In July, 1953, ten of these contested cases were still undisposed of.

\section{Table D-Actions Filed}

\begin{tabular}{|c|c|c|}
\hline 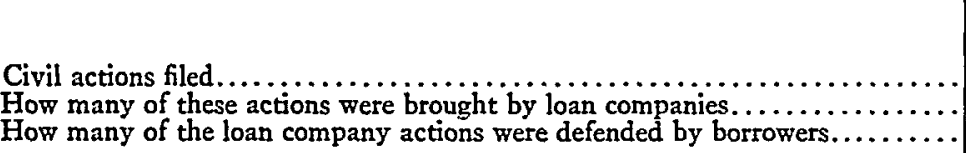 & $\begin{array}{c}\text { Number } \\
\text { of Cases } \\
7,186 \\
389 \\
30\end{array}$ & $\begin{array}{c}\text { Per Cent } \\
\text { of the } 7,186 \\
100.0 \\
5.4 \\
0.4\end{array}$ \\
\hline 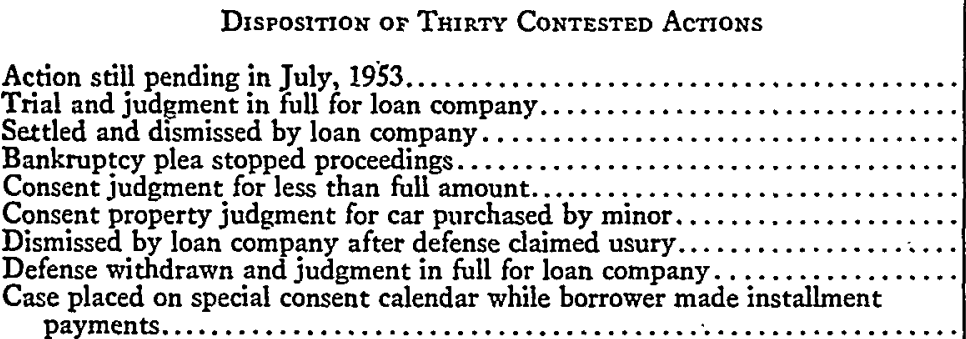 & $\begin{array}{c}\text { Number } \\
10 \\
7 \\
6 \\
2 \\
1 \\
1 \\
1 \\
1 \\
1\end{array}$ & $\begin{array}{l}\text { Per Cent } \\
\text { of } 30 \\
33.4 \\
23.4 \\
20.0 \\
6.7 \\
3.3 \\
3.3 \\
3.3 \\
3.3 \\
3.3\end{array}$ \\
\hline
\end{tabular}


Study of Legal Aid Case Records in January and February, 1953, to See What the Majority Were About and How Many Involved Loan Companies

The following table gives an analysis of 722 cases handled at the Legal Aid office in January and February, r953. The previous year domestic relations cases

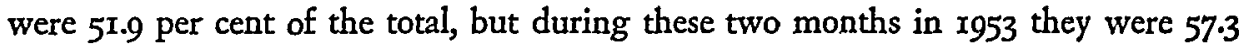
per cent. Loan company cases also rose from 2.9 per cent in 1952 to 3.3 per cent during these two months. Although 3.3 per cent were complaints against loan companies, more ( 7.2 per cent) were complaints against credit furniture, jewelry, and clothing stores; 0.4 per cent were complaints against employment agencies. In working on the domestic relations cases it has been found that debts to credit stores and loan companies have in many instances aggravated the marital trouble and contributed to the break-up of the family.

TABLE E

\begin{tabular}{|c|c|c|}
\hline 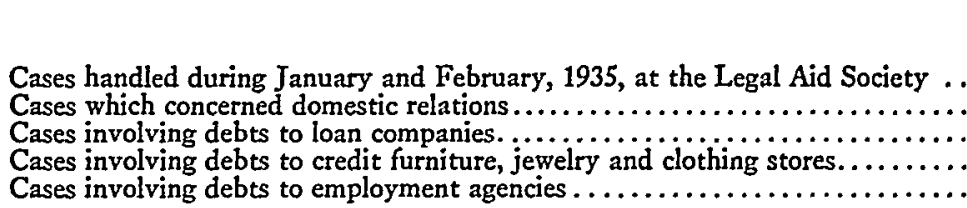 & $\begin{array}{l}\text { Number } \\
722 \\
414 \\
24 \\
52 \\
3\end{array}$ & $\begin{array}{c}\text { Per Cent } \\
\text { of } 722 \\
100.0 \\
57.3 \\
3.3 \\
7.2 \\
0.4\end{array}$ \\
\hline
\end{tabular}

Survey of 2121 Legal Aid Clients During i953 to See How Many Were in Debt to Loan Companies

During the months of March, April, May, June, and July, I953, a total of 2,12I applicants at the Society were questioned about their indebtedness to loan companies. They were asked if the lender had treated them fairly, and if not, what their complaint was. They were also asked how they happened to become involved with the lender and what charges they were paying for the money. It is not an easy task to get the facts from these troubled persons since they are usually confused themselves and incoherent. Much time must be spent probing, to determine when the loan was made, how much money was borrowed, and how much was to be repaid. A good many of the clients interviewed did not remember the name of the company they owed, could not tell how much they had borrowed or what they were supposed to pay back, or when they were to make the payments. Some did not remember why they borrowed the money. A good number upon giving their story, would, when the attorney reviewed it, give a new and different set of facts. For these reasons it is somewhat difficult to put in writing their troubles. However, an effort has been made to reduce their thoughts to writing, and the following tables summarize their beliefs.

Although less than 2 per cent of the cases at the Society for the years 1945 through r952 concerned loan problems, the following table shows that 18.7 per cent of the 2,I2I clients interviewed admitted being in debt to loan companies. The Society 
case records on these same clients show that an additional 7.3 per cent were in debt to mortgage holders on their homes. This makes a total of 26 per cent admittedly in debt. Of the 396 answering the survey questions that they owed loan companies, 64.9 per cent were Negroes and 35.I per cent white people. The negro population of the area remains a fertile field for the loan companies. The 396 cases involved 457 different loan transactions. One hundred thirty-three of those questioned gave the amount they had borrowed, and this totaled \$3x,309.00, or an average borrowing of $\$ 235.34$ for each person. The average income for these persons was $\$ 25$ to $\$ 50$ a week, with generally four or more persons dependent on it.

Table $\mathrm{F}$

\begin{tabular}{|c|c|c|}
\hline 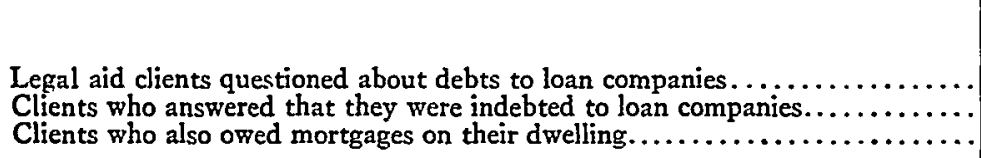 & $\begin{array}{c}\text { Number } \\
2121 \\
396 \\
155\end{array}$ & $\begin{array}{c}\text { Per Cent } \\
\text { of } 2121 \\
100.0 \\
18.7 \\
7.3\end{array}$ \\
\hline 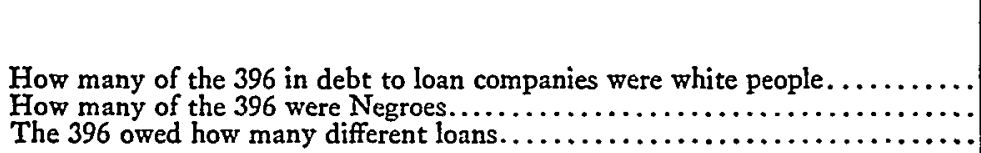 & $\begin{array}{c}\text { Number } \\
139 \\
257 \\
457\end{array}$ & $\begin{array}{c}\text { Per Cent } \\
\text { of } 396 \\
35.1 \\
64.9\end{array}$ \\
\hline
\end{tabular}

The following tables show how many of the 396 said they were satisfied with the way treated by their loan companies, how many were dissatisfied, and the nature of their complaints. Many said the loan company had treated them "nice" or "fine," and had been a real friend. In some instances the complaints had no legal basis, but the clients believed they had been treated unjustly. In other instances the complaints were legally justified, and relief was obtained.

The following table (p.gI) is an analysis of the reasons given by the borrowers for getting involved, expressed in their own words as much as possible. The largest group (21.2 per cent) were in debt to loan companies because of accumulated small bills. In many instances some of these smaller bills were due other loan companies. The next category (rI.3 per cent) were in debt because of illness. These low-income people seldom have money in reserve for even a short illness. The next category (I0.9 per cent) got in their difficulty so they could have a car. Many of them simply could not afford a car, and eventually lost it. Later they had judgments against them for deficiencies after the finance companies repossessed and sold the cars. The

TABLE G

\begin{tabular}{|c|c|c|}
\hline 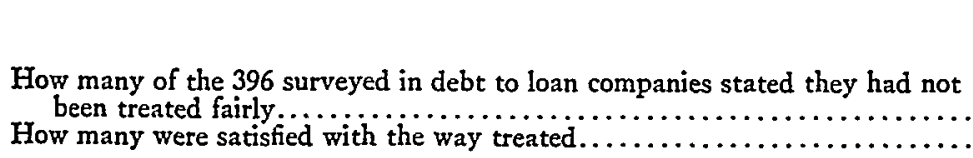 & $\begin{array}{c}\text { Number } \\
50 \\
346\end{array}$ & 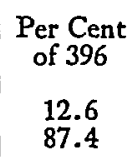 \\
\hline
\end{tabular}


TABLE H-Complaints of 50 Borrowers

Lender should have given borrower more opportunity to pay before repossessing or suing. . . Num 12

Lender charged too much for loan. ................................... 10

Borrower had to go to different loan companies to pay bills and other loan companies, and

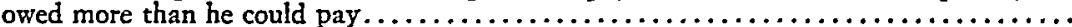

Lender should have made husband pay because he had persuaded wife to sign and he used

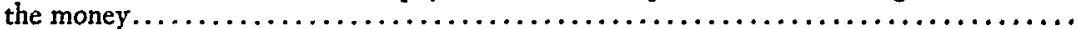

Lender should not have sued after repossessing car, because car was no good..............

Lender tried to force client to pay by threatening to sue husband for loan wife made.......

Lender tried to force borrower to pay by threatening to sue although borrower had completed

Lender tried to force borrower to pay by threatening to run garnishment before he sued and also to take borrower's furniture, which was not put up as security.$\ldots \ldots \ldots \ldots \ldots \ldots$

Lender tried to force client to pay by threatening to sue on a loan client did not sign for....

Lender broke his promise to wait 5 days before selling car repossessed, and when borrower took money within 5 days he found car already sold . . . . . . . . . . . . . . . . . .

Lender broke promise to get car from storage where placed by police after recovered from thief and impounded; instead sued borrower. $\ldots \ldots \ldots \ldots \ldots \ldots \ldots \ldots \ldots \ldots \ldots$

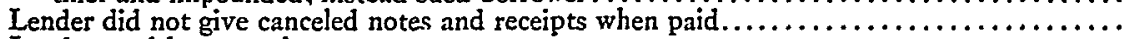

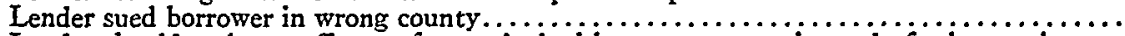

Lender should make an effort to force principal borrower to pay instead of suing co-signer. .

Lender should not have had borrower jailed on bail trover action when it knew the goods put up as security belonged to co-signer and borrower could not produce them............

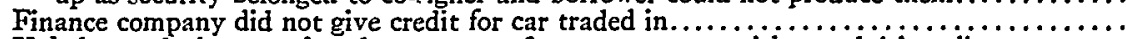

Upholstery dealer transferred contract to finance company without advising client..........

Finance company wrongfully repossessed car when co-signer paid note due and reported

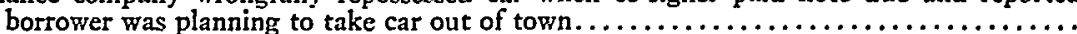

Borrower believed lender did not have right to take physical possession of article put up as

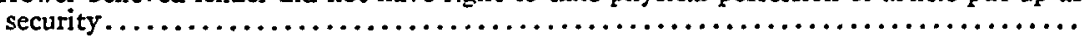

Total........ 50

next category ( 8.6 per cent) became involved because they needed to buy furniture. Frequently their incomes are not sufficient to buy necessary beds for their families. It is interesting to note that 3.0 per cent got in debt to help a relative and 0.5 per cent to help a friend. They could scarcely support themselves, but borrowed to help others. The scheme of giving old customers $\$ \mathrm{I}$ or $\$ 2$ to bring in new borrowers is frequently found, and it is apparently successful; thus 2.2 per cent became involved because they were taken to the loan office by a relative or friend.

The story of I.3 per cent who as wives put their names on loan papers and mortgaged their furniture because their husband requested it, is a pathetic one. A large number of the wives asking the Society to obtain support for the children from deserting fathers, have thus signed for the husbands to get money, which the latter used to leave town. The family has then been left with no support from the husband, and no way to pay the mortgage on the furniture.

Among the others, 3.8 per cent needed money for clothing, 3.5 per cent for food and rent, and $\mathrm{x} .7$ per cent for utility bills. Their regular incomes were not sufficient to provide food, shelter, and clothing for their families.

In addition, 0.5 per cent borrowed to pay for a funeral. Too often these families carry no life insurance to take care of a funeral. Finally, 4.0 per cent borrowed for celebration at Christmas, and 0.3 per cent for Easter. Many spent the rest of the year paying for the celebration. 
TABLe I

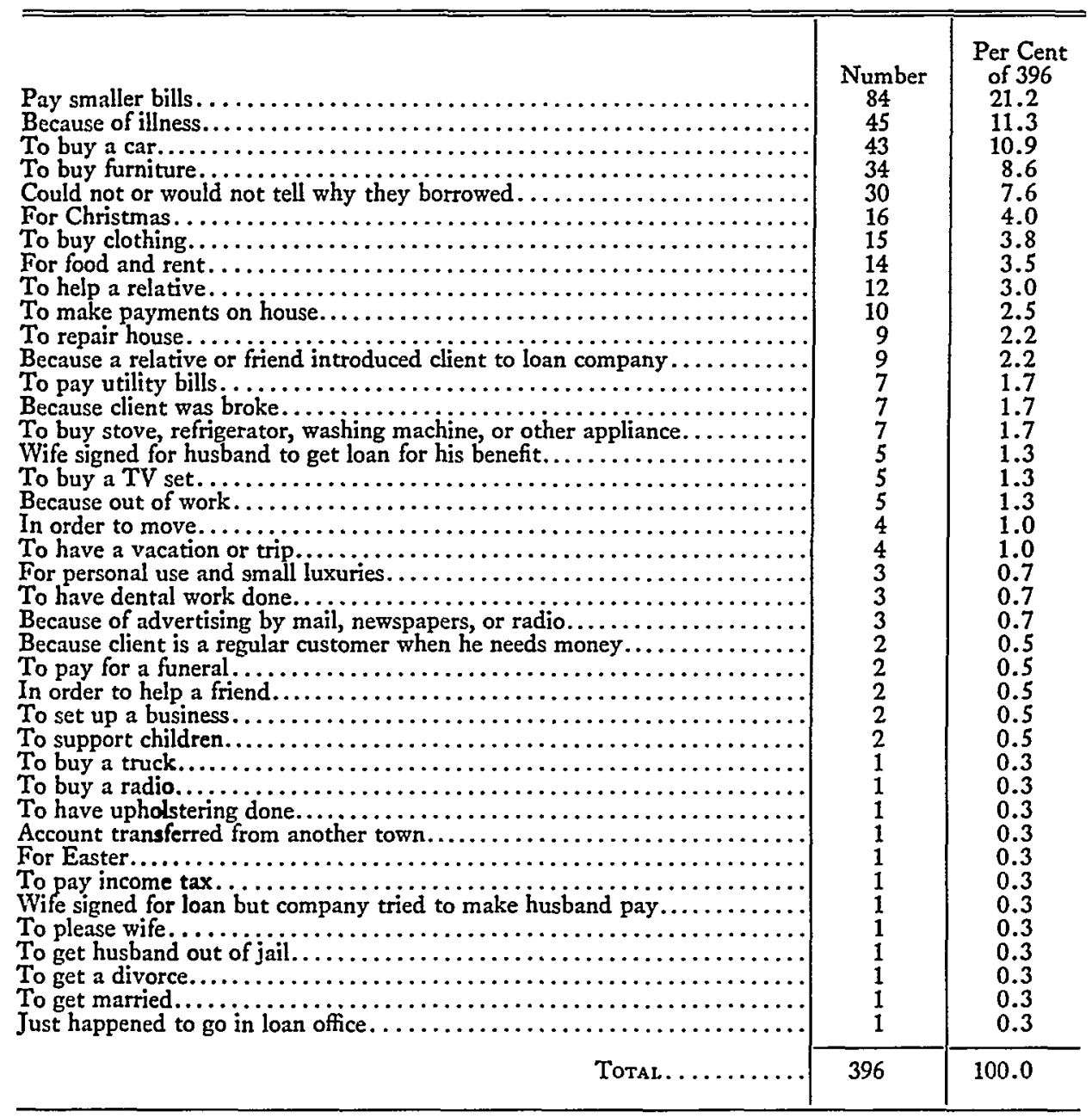

The following table shows that out of the 396 borrowers only 4.8 per cent believed they knew the interest rate. It is pathetic that such a small portion attempted to find out what amount of interest was charged them, and most of these did not realize the actual amount of interest.

Frequently a client would be told the interest was 8 per cent, but the facts, upon investigation by the attorney, would turn out to be like the following case. This client is a clean, brown-skinned young widow, supporting herself and five children on wages of $\$ 24$ a week. She tells the Legal Aid lawyer that when she first became involved with the loan company she was not as bad off as now. At that time she just owed a few bills, but after she started borrowing, she still owed more bills, plus the loan company. Her cousin took her into the friendly loan office, where regular 
customers were offered $\$ 2$ in cash to bring in new borrowers. When she told the loan company her assets were a $\$ 24$ a week job and a bedroom suite, her credit was approved and she was given $\$ 20$. She did not understand the papers she signed, but remembered that she was to re-pay the $\$ 20$ in 6 installments of $\$ 4.66$, payments to be made twice a month. Although she used the $\$ 20$ to pay on some of her bills, it did not go far, and when she returned to the company to make a payment, she so urgently needed more money that she accepted their offer to lend her more. When she reached the Society office she had borrowed the $\$ 20$ several more times, and had been paying over roo per cent interest per annum, but did not realize it.

TABLE J

\begin{tabular}{|c|c|c|}
\hline \multirow{3}{*}{$\begin{array}{l}\text { How many of the } 396 \text { stated they knew how much } \\
\text { interest was charged.................................... }\end{array}$} & Number & Per Cent of 396 \\
\hline & 19 & 4.8 \\
\hline & Number & $\begin{array}{l}\text { Per Cent Interest } \\
\text { Charged }\end{array}$ \\
\hline $\begin{array}{l}\text { How much interest these } 19 \text { persons believed } \\
\text { was charged } . \ldots \ldots \ldots \ldots \ldots \ldots \ldots \ldots \ldots \ldots \ldots \ldots \ldots \ldots \ldots \ldots\end{array}$ & $\begin{array}{l}1 \\
2 \\
2 \\
1 \\
1 \\
6 \\
3 \\
1 \\
1 \\
1\end{array}$ & $\begin{array}{r}3 \\
4 \\
6 \\
6-7 \\
6-8 \\
8 \\
10 \\
13 \\
15 \\
24\end{array}$ \\
\hline
\end{tabular}

The following table (p. 93) gives an analysis of $5^{6}$ of those answering in the affirmative the question regarding indebtedness to loan companies, who furnished full information on how much they borrowed and what they obligated themselves to pay. These $5^{6}$ persons had, according to their statements, borrowed a total amount of $\$ 7,982.00$ and had agreed to pay charges of $\$ 3, \mathrm{Ir} 2.18$ on the money borrowed. This shows an average borrowing of $\$ 142.54$ for each of the $5^{6}$ persons, and an average charge on the money borrowed of $\$ 55.57$ for each. The average cost of loan to each borrower was 93.7 per cent per annum, with no account taken of reduction of principal amount of debt by installment payments. These figures point up the profit possibilities of the loan business, and the lack of knowledge on the part of the borrowers.

A comparison was made of four loan companies patronized by the 396 clients surveyed, with the number of suits brought by these same companies in the Civil Court of Fulton County during January and February, I953. The following table sets forth this comparison, and shows that the company leading in popularity with the Society clients filed only I.3 per cent of the suits brought by loan companies. This particular company has, as a matter of fact, been cooperative with the Society attorneys, and has been lenient with its borrowers in making late payments. Al- 
Loan Shark Problem in Atranta, Ga.

Table K-Analysis of 56 Loan Transactions

\begin{tabular}{|c|c|c|c|c|c|}
\hline $\begin{array}{l}\text { Amount } \\
\text { Borrowed }\end{array}$ & $\begin{array}{c}\text { Charges for } \\
\text { Loan }\end{array}$ & $\begin{array}{l}\text { Number of } \\
\text { Months Loan } \\
\text { to Run }\end{array}$ & $\begin{array}{l}\text { Per Cent of } \\
\text { Principal } \\
\text { Charged Dur- } \\
\text { ing Length } \\
\text { of Loan }\end{array}$ & $\begin{array}{l}\text { Per Cent of } \\
\text { Principal } \\
\text { Charged by } \\
\text { Month }\end{array}$ & $\begin{array}{l}\text { Per Cent of } \\
\text { Principal } \\
\text { Charged by } \\
\text { Year }\end{array}$ \\
\hline 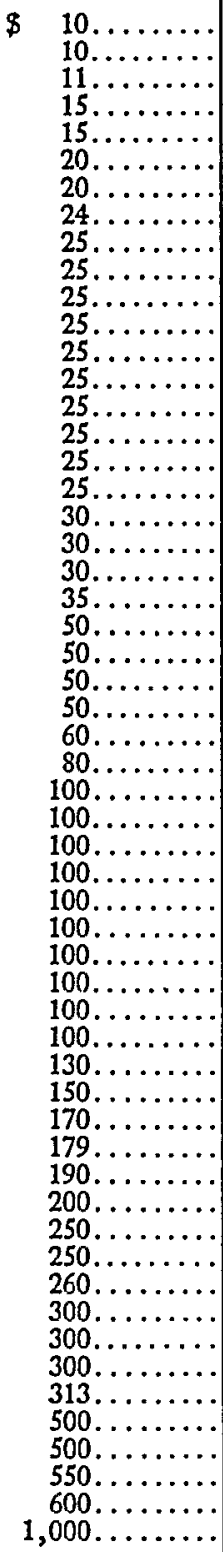 & $\begin{array}{r}1.90 \\
1.00 \\
1.10 \\
6.00 \\
6.78 \\
7.60 \\
7.96 \\
8.00 \\
4.50 \\
11.00 \\
8.00 \\
10.00 \\
10.28 \\
10.50 \\
10.75 \\
10.75 \\
11.00 \\
12.00 \\
5.76 \\
13.00 \\
12.00 \\
13.00 \\
7.25 \\
17.15 \\
26.50 \\
7.50 \\
7.20 \\
20.00 \\
8.00 \\
8.00 \\
8.00 \\
8.00 \\
14.40 \\
20.00 \\
21.00 \\
21.00 \\
29.60 \\
44.00 \\
130.00 \\
76.50 \\
154.00 \\
46.00 \\
93.50 \\
59.20 \\
110.00 \\
75.50 \\
268.00 \\
24.00 \\
60.00 \\
60.00 \\
87.00 \\
100.00 \\
490.00 \\
220.00 \\
84.00 \\
524.00\end{array}$ & $\begin{array}{l}1 \\
1 / 4 \\
1 \\
3 \\
3 \\
3 \\
3 \\
8 \\
3 \\
6 \\
3 \\
3 \\
3 \\
3 \\
3 \\
3 \\
3 \\
1 \\
3 \\
4 \\
3 \\
4 \\
3 \\
3 \\
4 \\
1 \\
6 \\
10 \\
12 \\
12 \\
12 \\
12 \\
10 \\
12 \\
11 \\
11 \\
12 \\
12 \\
24 \\
8 \\
18 \\
15 \\
18 \\
12 \\
12 \\
12 \\
24 \\
12 \\
24 \\
24 \\
10 \\
12 \\
18 \\
60 \\
18 \\
24\end{array}$ & $\begin{array}{r}19.0 \\
10.0 \\
10.0 \\
40.0 \\
45.2 \\
38.0 \\
39.8 \\
33.3 \\
18.0 \\
44.0 \\
32.0 \\
40.0 \\
41.1 \\
42.0 \\
43.0 \\
43.0 \\
44.0 \\
48.0 \\
19.2 \\
43.3 \\
40.0 \\
37.1 \\
14.5 \\
34.3 \\
53.0 \\
15.0 \\
12.0 \\
25.0 \\
8.0 \\
8.0 \\
8.0 \\
8.0 \\
14.4 \\
20.0 \\
21.0 \\
21.0 \\
29.6 \\
44.0 \\
100.0 \\
51.0 \\
90.6 \\
25.7 \\
49.2 \\
29.6 \\
44.0 \\
30.2 \\
103.1 \\
8.0 \\
20.0 \\
20.0 \\
27.8 \\
20.0 \\
98.0 \\
40.0 \\
14.0 \\
52.4\end{array}$ & $\begin{array}{r}19.0 \\
40.0 \\
10.0 \\
13.3 \\
15.0 \\
12.7 \\
13.3 \\
4.2 \\
6.0 \\
7.3 \\
10.7 \\
13.6 \\
13.7 \\
14.0 \\
14.6 \\
14.6 \\
14.7 \\
48.0 \\
6.4 \\
10.8 \\
13.3 \\
9.3 \\
4.8 \\
11.4 \\
13.2 \\
15.0 \\
2.0 \\
2.5 \\
0.7 \\
0.7 \\
0.7 \\
0.7 \\
1.4 \\
1.7 \\
1.9 \\
1.9 \\
2.5 \\
3.7 \\
4.2 \\
6.4 \\
5.0 \\
1.7 \\
2.7 \\
2.4 \\
3.7 \\
2.5 \\
4.3 \\
0.7 \\
0.8 \\
0.8 \\
2.7 \\
1.7 \\
5.4 \\
0.7 \\
0.8 \\
2.2\end{array}$ & $\begin{array}{r}228.0 \\
480.0 \\
120.0 \\
160.0 \\
180.8 \\
152.0 \\
159.2 \\
50.4 \\
72.0 \\
88.0 \\
128.0 \\
160.0 \\
164.4 \\
168.0 \\
172.0 \\
172.0 \\
176.0 \\
576.0 \\
76.8 \\
129.9 \\
160.0 \\
111.3 \\
58.0 \\
137.2 \\
159.0 \\
180.0 \\
24.0 \\
30.0 \\
8.0 \\
8.0 \\
8.0 \\
8.0 \\
16.8 \\
20.0 \\
22.8 \\
22.8 \\
29.6 \\
44.0 \\
50.0 \\
76.8 \\
60.0 \\
20.4 \\
32.8 \\
29.6 \\
44.0 \\
30.2 \\
51.5 \\
8.0 \\
10.0 \\
10.0 \\
32.4 \\
20.0 \\
64.8 \\
8.0 \\
\end{array}$ \\
\hline$\$ 7,982$ & $\$ 3,112.18$ & $5551 / 4$ & & & \\
\hline
\end{tabular}


though the rates charged are legal, still frequently their borrowers are actually paying dearly for the money. The loan may cost almost 32 per cent plus other charges, and many of these advances are "package" loans, used to pay off principal and interest due other loan companies. Frequently on these loans the client cannot tell the amount advanced, since it was not paid to him but to other loan companies and other creditors, and he does not remember the amounts of these debts either.

It is interesting to note that the " $\mathrm{A}$ " Loan Company which filed the largest number of suits in the period checked had only 0.2 per cent of the Society clients as customers. If more borrowers could figure charges and compare the ways of doing business by the various companies, they could choose lenders who stayed within the law. Also if they could develop some sales resistance, they could better withstand the attractive advertising and select their loan companies on the basis of worth rather than empty promises. This is difficult for them when they see and hear generous offers of the loan companies in letters, newspapers, and over the radio, and when they so desperately need the money. The advertisements say that the loan company has a friendly confidential service, and that it can clean up their current bills, and give them extra cash too-it can, in fact, remove the borrowers' financial worries. Sometimes these needy people receive in the mail vouchers for certain amounts of money from the loan companies, with an invitation to come into the loan office and get the money after their credit is checked. They are urged to come quickly before the rush begins. Such offers are hard to resist to those who need money to buy groceries.

Table L-Comparison of Popularity of Four Loan Companies With 396 Legar Aid Clients Surveyed, and Number of Suits Filed in the Civil Court op Fulton County in JaNUARY and February, 1953, by These Compantes

\begin{tabular}{|c|c|c|}
\hline Name of Loan Company & Number of Suits Filed & $\begin{array}{c}\text { Per Cent of } 389 \text { Suits Filed } \\
\text { by Loan Companies }\end{array}$ \\
\hline 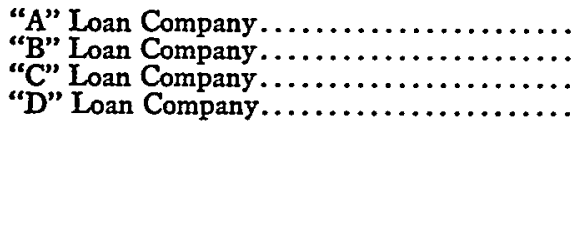 & $\begin{array}{c}20 \\
18 \\
5 \\
2 \\
\\
\text { Number of Clients } \\
\text { Patronizing }\end{array}$ & $\begin{array}{c}5.1 \\
4.6 \\
1.3 \\
0.5 \\
\\
\\
\text { Per Cent of the } 396 \\
\text { Interviewed }\end{array}$ \\
\hline 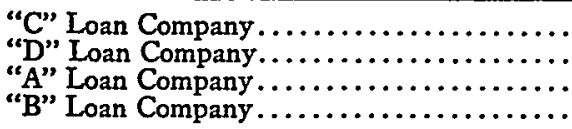 & $\begin{array}{r}72 \\
57 \\
7 \\
3\end{array}$ & $\begin{array}{r}18.2 \\
14.4 \\
0.2 \\
0.1\end{array}$ \\
\hline
\end{tabular}

\section{Conczusions}

From many interviews with borrowers at the Society office, it appears that borrowers are reluctant to complain against their loan company friends. Many are afraid they will lose their jobs unless they settle with the loan company before the 
boss finds out about it. They know that many employers will fire a fellow unless he promptly settles a garnishment. Many fear going to court and prefer paying the loan companies rather than having their cases heard by the court, even though they are assured of a fair hearing and a good possibility of winning. Many consider the loan companies real friends who have helped them when in need. Many are very proud of their credit rating, and the fact that the loan company trusts them enough to give them money.

There have been many instances at the Society office in which cases with loan sharks have been successfully concluded for clients. These clients invited their friends to come in for the same service in regard to the usurious money lenders, but the friends would not come in. Many are afraid that when they need to borrow again they will be blacklisted; they know from past experience that the time will come when they need cash for "smaller bills," the landlord, or to buy something they want and cannot otherwise purchase.

There is reason to believe that those people above the Legal Aid income level are even more reluctant to admit that they are indebted to loan companies, as they are ashamed for the fact to be known.

It is a fact that most borrowers of small sums are ignorant and unable to protect themselves. They cannot understand the papers presented them for signature, and cannot figure well enough to know how much the loan is actually going to cost them and whether their income is sufficient to meet the payments.

There is need to enlist the interest and efforts of more people in the loan shark evil, especially employers, personnel managers, and other civic groups. Although the situation is improved over that existing in the early years of the Legal Aid Society in Atlanta, still much suffering results from money lending abuses. Many are the persons who borrow at high rates to pay their bills, put up all their furniture as security, then cannot meet the payments, lose the furniture, are sued for a deficiency; judgment is issued against them by default, and then garnishment follows. Most of these borrowers have large families and their dependents suffer a real hardship.

In the long run better education of these persons will help them solve their own problems. More adequate laws on money lending are also greatly needed.

In the meantime a great service can be given these citizens by their employers, who can furnish them with information on the loan shark problem and cooperate with them when they are involved, instead of firing them. Better work for the employer would result from less worried workers. Also of tremendous help would be the availability of more legal aid and the dissemination of more information explaining how to get legal service. By timely consultation with an attorney many borrowers could save themselves judgments and garnishments, which are contrary to law, but which issued because of the borrowers' default, and thus they could save their families needless suffering. 